\title{
Ecology of the Endemic Land Crab Fohngarthia malpilensis (Decapoda: Brachyura: Gecarcinidae), a Poorly Known Species from the Tropical Eastern Pacific ${ }^{1}$
}

\author{
Mateo López-Victoria ${ }^{2,3,4}$ and Bernd Werding ${ }^{3}$
}

\begin{abstract}
Fohngarthia malpilensis (Faxon, 1893) is the least studied of the eight American species of Gecarcinidae. This land crab is considered endemic to Malpelo, an oceanic island of the Colombian Pacific. Several aspects of its ecology were investigated between 2003 and 2006. We estimated its population density, distribution, daily activity, reproduction, interactions, and diet by marking and monitoring 909 individuals. During our visits we recorded crabs of sizes from 5 to $82 \mathrm{~mm}$ carapace width. Fohngarthia malpilensis shelters mainly in fissures and hollows between rocks. It is distributed all over the main island except in very steep sectors. An average density of 0.41 adults $\mathrm{m}^{-2}$ and 0.55 juveniles $\mathrm{m}^{-2}$ produced an estimated total population of 833,000 . Fohngarthia malpilensis showed high mobility, with crabs covering distances over $450 \mathrm{~m}$ in a few days on highly irregular surfaces. Activity was higher from dusk till dawn and lowest around noon. Release of larvae took place during the high tides associated with the new moon, at least during the rainy season. It is omnivorous and opportunistic, consuming practically every available resource. The crab is occasionally preyed upon by an endemic lizard and migratory birds. Its general ecology is very similar to that of $\mathcal{F}$. planatus, a closely related species. As a voracious omnivore 7. malpilensis is one of the most important components of Malpelo's food web.
\end{abstract}

Crabs of the family Gecarcinidae have a pantropical distribution and live mainly in coastal environments with different types of vegetation and soils. Although some species are able to survive kilometers from the coasts and over $1,000 \mathrm{~m}$ above sea level, all studied species must return to the sea to release their larvae, which, after a period in the plankton, return to the mainland as megalops or first crab stages (Wolcott 1988). All species are limited by humidity levels in their branchial

\footnotetext{
${ }^{1}$ This investigation was partially supported by the Marine and Coastal Research Institute (INVEMAR), the Colombian Institute for the Development of Science and Technology (COLCIENCIAS) (Project 2105091352703), the Department of Animal Ecology at the Justus-Liebig-University of Giessen, the German Academic Exchange Service (DAAD), the Malpelo Foundation, the Special Administrative Unit for the System of National Natural Parks of Colombia, and the Colombian
}

Pacific Science (2008), vol. 62, no. 4:483-493

(C) 2008 by University of Hawai'i Press

All rights reserved cavities and their osmotic balance. Almost all construct burrows, have a varied diet (from vegetarian to omnivorous), and show sexual dimorphism, with males having larger chelae than females (for reviews see Türkay 1987, Burggren and McMahon 1988, Ng and Guinot 2001, Hartnoll et al. 2006).

Johngarthia malpilensis (Faxon, 1893), generally referred to in the literature as Gecarcinus (Johngarthia) malpilensis (for a revision of its nomenclature see Türkay 1970, 1987,

Navy. This study was supported in the field by the Colombian Navy ships ARC Malpelo, ARC Valle del Cauca, and ARC Caldas, as well as by the ship Maria Patricia, the ship Anita, and U.S. National Oceanic and Atmospheric Administration research vessel David Starr fordan. This is contribution 992 of INVEMAR. Manuscript accepted 31 October 2007.

${ }^{2}$ Corresponding author (e-mail: mateo.lopezvictoria@uni-giessen.de).

${ }^{3}$ Department of Animal Ecology, Justus-LiebigUniversity of Giessen, Heinrich-Buff-Ring 29, 35392, Germany.

${ }^{4}$ Marine and Coastal Research Institute (INVEMAR), Santa Marta, Colombia. 
Hartnoll et al. 2006), is an orange to pale pink terrestrial crab; its appearance varies according to age and molt condition: some large individuals are pink with pale blue green tones. The crab lives only on Malpelo Island, Colombia, and is the only such limited endemic of the family in the Americas (Türkay 1970). Its taxonomic status has been debated (Garth 1948), and it has been considered a synonym of 7. planatus (Stimpson, 1860) (Rathbun 1918, Prahl 1990), a species widely distributed in other islands of the tropical eastern Pacific. However, 7. malpilensis is referred to as a discrete species by most recent authors (Türkay 1970, 1987, Ng and Guinot 2001, Hartnoll et al. 2006), though its taxonomic status requires further investigation. Fohngarthia malpilensis is one of the most important components of the island's terrestrial fauna, but apart from the original description (Faxon 1893) and some taxonomic notes (Garth 1948, Türkay 1970), only marginal commentaries have been made on the ecology of this crab in various general studies on Malpelo (Prahl 1990, Brando et al. 1992). As a result of substantial recent field observations we present observations on the general biology, density, distribution, daily activity, diet, and ecological interactions of the crab.

\section{Study Area}

Malpelo and the 11 neighboring islets are located $380 \mathrm{~km}$ west of Colombian mainland territory and have an emerged area of $\sim 1.2$ $\mathrm{km}^{2}$ (Figure 1), with a maximum elevation of $300 \mathrm{~m}$ (López-Victoria and Rozo 2006). Malpelo is located in a zone of converging marine currents, in the confluence of trade winds from north and south forming a cloudy belt known as the Intertropical Convergence Zone. Thus the island is subject to considerable precipitation and humidity (Graham 1975, Prahl 1990). The majority of the island surface is bare of vegetation, except for microalgae covering the rocks, some lichens and mosses, some isolated patches of grass, and the creeping fern Pityrogramma dealbata (Presl, 1825). The land fauna of Malpelo is adapted to the rocky substrate and depends on the scarce vegetation and on the nutrients provided by the sea via seabirds (Graham 1975), mainly the Nazca Booby, Sula granti Pitman \& Jehl, 1998, which has its largest breeding colony on the island (Pitman and Jehl 1998). The avian fauna is composed of 10 resident seabird species and about 50 vagrant and migratory species that provide the system with excrement rich in phosphate and minerals and thus fertilize the scarce vegetation (mainly microalgae). Besides the land crab and the birds, the terrestrial fauna of Malpelo is composed of three endemic lizards, Anolis agassizi Stejneger, 1900; Diploglossus millepunctatus O'Shaughnessy, 1874; and Phyllodactylus transversalis Huey, 1975, and ca. 60 invertebrate species (Wolda 1975, Prahl 1990).

Observations and experiments were carried out during eight visits between October 2003 and September 2006 in the vicinity of five sectors selected according to their distance to the sea, elevation, and accessibility (Figure 1). The Tangon sector $(0-20 \mathrm{~m}$ height) is located in the mid-east of the island and comprises a rocky cliff of variable slope; the only access to the island is located here. The Punta Este sector (100-140 m height) is also in the mid-east of the island, with a very irregular surface including many fissures and small caves. The Cabañas sector (110-120 m height) is on the east of Malpelo and is the only large level terrain of the island with soil. Two small houses for the Colombian Navy garrison are located there. The Cerros sector (260-270 m height) lies in a depression between the peaks of the two central hills: its surface is very irregular and has variable slope. The Sur sector (140-150 m height), in the south, lies on a fracture zone with a mild slope and very irregular substrate.

\section{MATERIALS AND METHODS}

Measurements were made of carapace width (CW) and weight for 46 adult female crabs, 76 adult males, and 69 juvenile-immature individuals $(<3.5 \mathrm{~cm} \mathrm{CW})$. These data were collected in five sectors (Figure 1). Observations were made of the crab's feeding behavior as well as of the shape and form of its refuges. For these observations individuals 


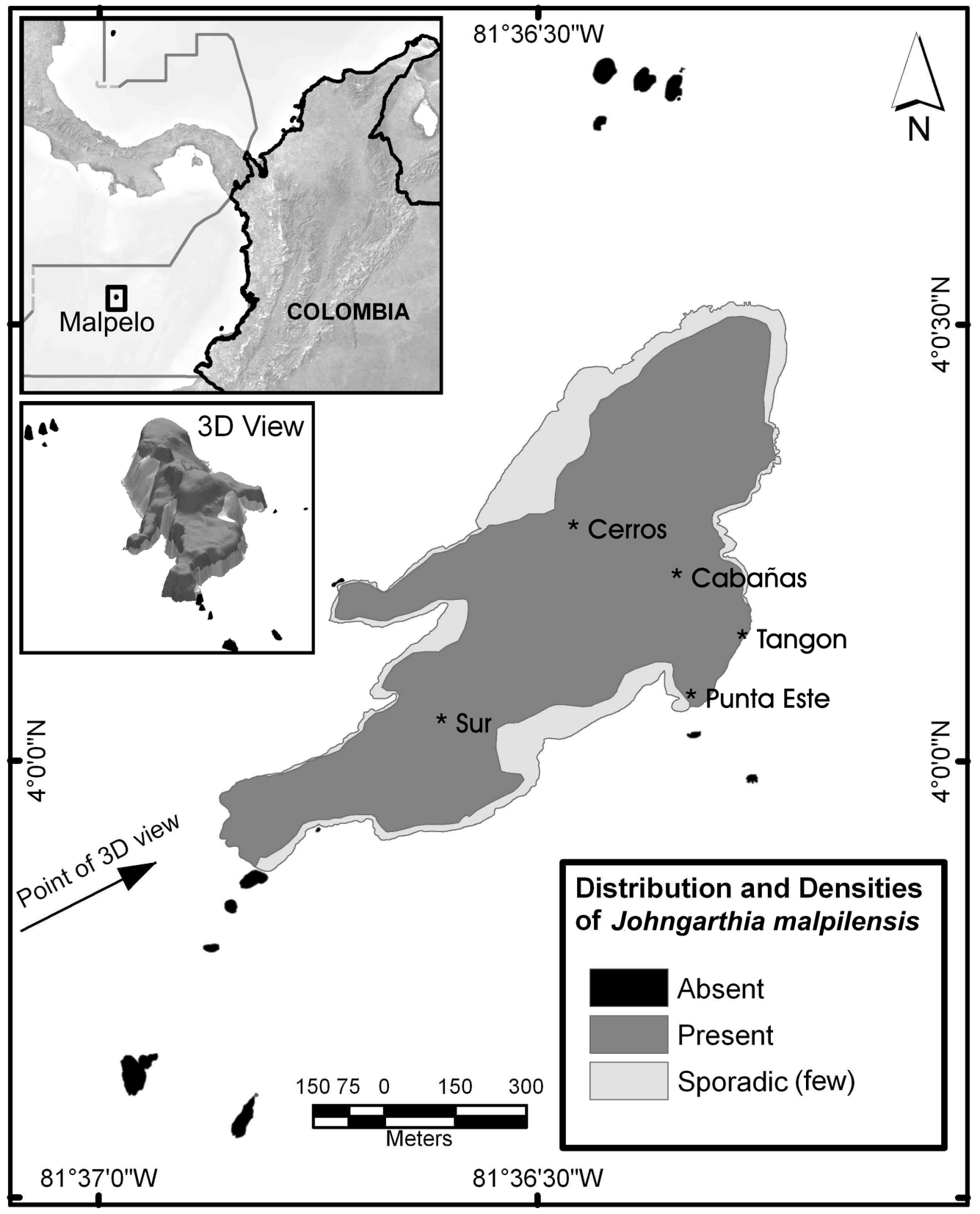

Figure 1. Map of Malpelo Island indicating the main sampling sites mentioned in the text and the distribution of fobngarthia malpilensis. 
were followed for several minutes on different days and at different hours. All the average values are followed by \pm 1 standard error (SE).

To estimate abundance, population size, and distribution of Fohngarthia malpilensis, its presence or absence was recorded during a survey of the island and some of the islets. To estimate the average adult density, 29 square plots $(10$ by $10 \mathrm{~m})$ were established at dusk in different sectors on the eastern side of the island. To estimate average juvenile density, eight band transects ( 20 by $2 \mathrm{~m}$ ) were censused at night. All squares and band transects were conducted in similar areas; because of the lack of higher vegetation the island's habitat was considered uniform for these purposes. Population size was estimated by extrapolating the average density data to the total distribution area established for the crabs in the island, using a Digital Elevation Model (see López-Victoria and Rozo 2006). To evaluate mobility and site fidelity, displacement of 125 adult crabs marked with a number on the carapace was followed (25 crabs on each of the five sectors), as well as the displacement of another 784 crabs marked with letters according to the sectors. Recaptured crabs were marked again, adding the letter of the place where they were found again.

The daily activity pattern was evaluated on two fixed sites of 4 by $4 \mathrm{~m}$, where total number of individuals was already known. The observations were conducted during seven day-night cycles almost around the clock. Measures were taken at 1- to 2-hr intervals. Data on relative humidity (\% RH; accuracy $\pm 2.5)$ and temperature $\left({ }^{\circ} \mathrm{C}\right.$; accuracy \pm 0.8$)$ were measured using an electronic meter (Volkraft HT-200), placing the sensor $3 \mathrm{~cm}$ above the soil (external measure) or at the bottom of the crab's shelter (internal measure). Activity was expressed as the number of individuals out of their shelters and moving in the sites. Correlations and polynomial regressions were made between time of day, crab activity, humidity, and temperature.

Ovigerous females were monitored in the Tangon sector. All copulations were recorded for duration, locality, and whether the female was ovigerous. Release of larvae and presence of ovigerous females near the sea were examined with respect to moon phase, in particular around periods of new moon, based on observations conducted throughout a month between May and June 2006.

We made detailed observations on the interactions between the crabs and the tetrapods in Malpelo, as well as the interactions among crabs. Predation and competition for food were recorded through marking and following crabs over various time intervals. To examine the relationship between crabs and breeding Nazca Boobies, 30 chicken eggs of size, weight, and color similar to those of the seabird were placed as follows: 21 in empty nests and nine between nests. Behaviors during the crabs' examination of eggs, eating by the crabs, and interactions with lizards and birds during this process were recorded.

\section{RESULTS}

Average weight of adult females was $64.5 \mathrm{~g}$ $( \pm 1.8)$, and of adult males $94.0 \mathrm{~g}( \pm 4.2)$. Maximum CW and body weight for females were $65.6 \mathrm{~mm}$ and $93.1 \mathrm{~g}$, respectively, and for males $82.1 \mathrm{~mm}$ and $180.0 \mathrm{~g}$. The smallest crab was $5.5 \mathrm{~mm} \mathrm{CW}$ and weighed less than $0.2 \mathrm{~g}$. A comparative analysis between females and males with similar CW (average width difference less than $2 \%$ ) showed differences in the average body weight of near $13 \%$. Such differences are attributable to the chelae size being much larger in males.

fohngarthia malpilensis cannot swim, but it can walk on the bottom of small ponds for short distances and times. Several individuals were observed scraping and eating green algae, semisubmerged or fully submerged in natural freshwater puddles: this may be important in replenishing body fluid level in preparation for molting.

Few areas of Malpelo are covered with soil, and most of its surface is naked basaltic rock. Fohngarthia malpilensis uses fissures and hollows between rocks as shelters, although it also digs burrows in the few places where 
the soil is deep enough. The galleries are interconnected and may be used by several individuals at the same time.

fobngarthia malpilensis is distributed over almost the entire island except some very steep sectors or cliffs (Figure 1). Both adults and juveniles were found everywhere, from sea level up to the highest peaks. Despite an intensive search in the islets, not a single crab was found there. An average density of $0.46 \pm 0.07$ individuals $\mathrm{m}^{-2}$ was estimated for adult crabs, whereas for juvenile crabs the average density was estimated at $0.55 \pm 0.10$ individuals $\mathrm{m}^{-2}$. The great variation in the density of individuals is attributable to the great crab concentration occurring in the Cabañas sector, where one of the squares showed a density of 2 individuals $\mathrm{m}^{-2}$, compared with other sectors where the lowest density was 0.1 individual $\mathrm{m}^{-2}$. Extrapolating the average density values $(0.41 \pm 0.04$ individuals $\mathrm{m}^{-2}$; excluding the highest value around the Cabañas sector) to the island surface occupied or visited by crabs (obtained from the Digital Elevation Model [see Figure 1]), the adult crab population actually living in Malpelo is nearly 350,000, and the juvenile crab population (less than $35 \mathrm{~mm} \mathrm{CW}$ ) is approximately 483,000. Both densities are underestimates because when the counts were made (at dusk), although the crabs showed great activity, it was not possible to ensure that the total population was out of the shelters. The same situation is applicable to the juvenile crab population because, although they are very active at night, they may hide in fissures without being detected by the observer.

Marking and recapture indicated that 7 . malpilensis shows high mobility, even when not in the breeding season. The most extreme cases, assuming a straight-line displacement between sectors, were observed in those individuals marked in Cerros sector and recaptured in Cabañas and later in Tangon sectors, covering distances of $450 \mathrm{~m}$ in 14 days, over an irregular and very steep terrain. Other extreme cases were observed in individuals marked in Cabañas, recaptured in Tangon some days later, and seen again in
Cabañas (distance: $420 \mathrm{~m}$ ). However, some individuals (especially from Cabañas sector) showed substantial fidelity to a sector and were marked and recaptured there several times over 60 consecutive days.

Adults' daily activity peaked at dusk, during the night, and in the early morning, with a drastic decrease at noon and the early afternoon. This general pattern was positively correlated with the relative humidity of the air (correlation $r=0.621, P<.01$ ), which was always higher within the crabs' shelters than outside, and negatively correlated with temperature $(r=-0.645, P<.01)$. Consequently, during and shortly after showers, even on overall warm days, crab activity increased. On the contrary, during very sunny and dry days, very few active crabs were observed, and the majority of those resting in their lairs had their eyes and legs completely folded against their bodies (fully asleep). In the late afternoon, and before and at dusk, greater crab activity was observed coinciding with the return to the colony of hundreds of Nazca Boobies coming back from their fishing activities. This increase in crab activity could be related to the birds' arrival and, therefore, to the increase of the excrement input to the system. Juvenile crabs were seen outside crevices only during the night.

Two forms of mating were observed. One occurred everywhere, not associated with shelters, and comprised the union of an adult nonovigerous female and a male. The female was briefly courted by the male, who uses his chelae to make rapid touches and rubbing of short duration on the female's carapace. The male seized the female 1 or $2 \mathrm{~min}$ after initial contact. Once they were face to face, they made contact with their walking legs, then the male covered the female's carapace with his chelae and then with his walking legs. When the couple was facing, the abdomens were unfolded, and the male inserted his gonopods in the gonopores of the female. The couple remained joined for up to an hour or more (Figure 2). During that time the male frequently rubbed the female's carapace while she remained static, her chelae folded against her body and her eyes sunk 


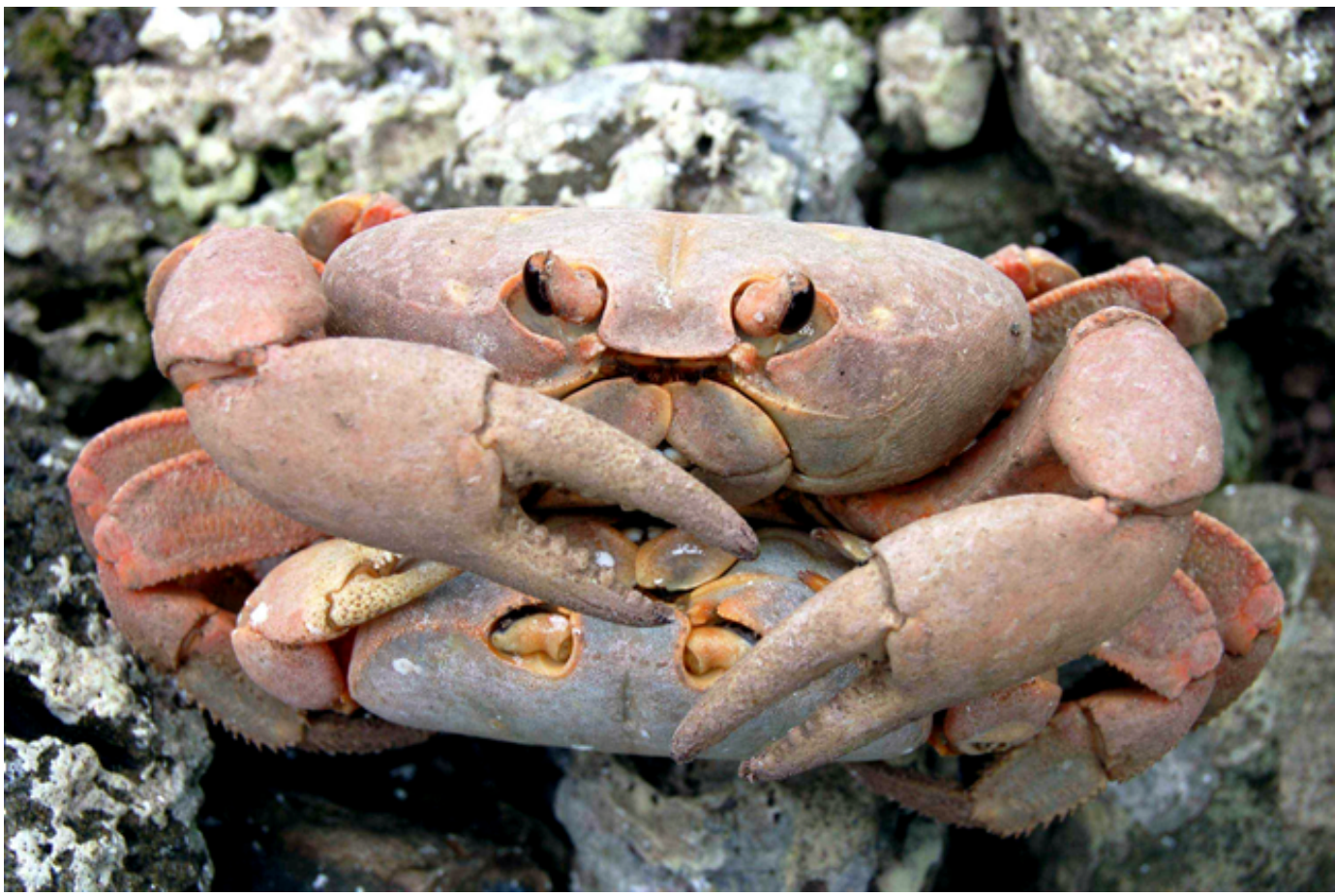

FIGURE 2. Fohngarthia malpilensis mating: the male above, the female (not having eggs) embraced by the male's chelae below.

in the orbits. On the contrary the male remained alert, with his eyes outside the orbits. When other crabs or lizards came close to the couple, the male displayed his chelae in a challenging attitude, driving off the intruder.

The other form of copulation followed a similar pattern but was limited to the zone near the sea (first 10 to $15 \mathrm{~m}$ of the cliffs) and involved very large males and ovigerous females. No precopulation display or visual recognition was observed before mating, and mating was not associated with shelters in any case. No preferences on timings for copulations were recognized.

Larval release was associated with the high tides of the days before, during, and after the new moon. Ovigerous females stayed in fissures and hollows close to the sea waiting for the high tide at dusk (in May-June 2006 between 1830 and $1930 \mathrm{hr}$ local time). Once the high tide was close or at its maximum, females walked slowly to where the waves washed the cliff, staying at the limit of maximum high tide level. At this point females waited for the highest wave's cycle and were immersed three or four times while shaking their abdomens, releasing larvae into the sea. After releasing larvae females rapidly climbed the cliff back to the supratidal zone. Twice during the May 2006 release of larvae, females were observed being swept away by the waves and did not return to land. Most hatching occurred on the 2 days following new moon, and then the number decreased nightly as the level of the maximum high tide decreased. All ovigerous females had old carapaces of pale color. Large males, apparently seeking to mate, joined the releasing females in fissures and hollows.

Johngarthia malpilensis is omnivorous and opportunist and will eat everything available, but its regular diet consists of microalgae that it scrapes from the rocky surfaces, bird excrement and feathers, and, seasonally, eggs, 
chicks, and juveniles of the Nazca Booby. This crab has a reliable access to the second chick of the Nazca Booby because this species practices siblicide, so that although it lays two eggs, the first chick expels the second from the nest and it invariably dies. This food source was frequently used during the months of high nesting activity, from June to November.

On all our visits up to nine crabs were seen constantly harassing each of the active nests of Nazca Booby. Nevertheless, on only three occasions did we observe a crab successfully stealing an egg. This was always followed by abandonment of the nest by the birds. Sporadically, the crabs fed on carcasses of other animals, particularly dead birds. Fresh carcasses were fully eaten within $24 \mathrm{hr}$. Marking studies showed that an initial group of 30 to 50 feeding crabs was replaced in a few hours by others once the first are satiated. Finally only a few hard remains of the bird were recognizable, such as parts of the pelvic girdle and the rachis of the primary feathers and retrices. Following marked individuals indicated that more than 400 crabs may feed from a single carcass of an adult Nazca Booby.

The crab sporadically cannibalizes juveniles by hunting at night among the rocks. It occasionally captures lizards or insects, and when near the shore it may feed in the intertidal zone on invertebrates and fleshy algae during low tides. They also feed on the only higher plant (the creeping fern Pityrogramma dealbata) on the eastern side of the island. Around the barracks of the Colombian Navy Station crabs eat leftovers and garbage dumped by marines and visitors.

Thirty chicken eggs were located experimentally in or among Nazca Booby nests: six were broken and expelled from the nest by a returning male before any crab located them. Five other eggs ended up exclusively as food for lizards (D. millepunctatus) or shared with the crabs. The remaining 19 eggs were eaten by one or more crabs, which seemed to find the eggs inadvertently. Rather than an active search motivated by visual or olfactory clues, the crabs responded to the presence of a "new" object in the surroundings. The crab recognized an egg immediately on contact with walking legs or chelae: it changed from regular random movement to a concentrated manipulation of the egg. In every case the crab raised the egg with its chelae and tried, in vain, to bite it with its mouthparts; then it started moving the egg from the site. Eggs were not opened by the crab using its chelae, but breakage resulted from transport over the rough ground or, on some occasions, during a dispute with another crab. When two or more crabs fought over an egg, the bigger crab (having bigger chelae) always kept the egg. Once the egg was broken, the crab started eating the contents and shell, which often attracted other crabs and lizards $(D$. millepunctatus) that came to steal part of the contents.

Individuals of all sizes of 7 . malpilensis are occasionally devoured by $D$. millepunctatus. Juveniles are swallowed whole, whereas adult crabs, after removal of the walking legs and chelae, are opened from the rear; the abdomen raised and the carapace removed. Interior soft parts are then eaten and sometimes also the appendages. Juvenile crabs are also preyed upon by $A$. agassizi (which swallows the crab in pieces) and by some migratory birds (i.e., herons, turnstones, and plovers). Although D. millepunctatus preys upon the crab, when competing for food, as with a carcass of a Nazca Booby, for example, crabs repel the lizards by exceeding them in number.

\section{DISCUSSION}

The appearance, size, and general biology of fohngarthia malpilensis is very similar to those of $\mathcal{F}$. planatus (a closely related sibling species), except that the latter has on many islands of the tropical eastern Pacific a more intense red orange color (R. Pitman, pers. comm.; M.L.-V., unpubl. data). This might be because those locations have substantial vegetation covers, and the intense coloration derives from the plants' pigments. Alternatively, dense vegetation cover may protect the crab from discoloration produced by sun- 
light. Both species have similar diet and living conditions, although on many islands of the tropical eastern Pacific (i.e., Clipperton, Socorro, Cocos, Gorgona) Johngarthia planatus burrows actively due to areas of soft soil that are easy to excavate (Ehrhardt and Niaussat 1970, Pérez-Chi 2005; R. Pitman, pers. comm.; M.L.-V., unpubl. data). In size 7 . malpilensis is intermediate among American gecarcinids, compared with the larger Cardisoma guanbumi Latreille, 1825 (maximum CW $\sim 130 \mathrm{~mm}$ ), and C. crassum Smith, 1870 (maximum $\mathrm{CW} \sim 130 \mathrm{~mm}$ ), and the smaller Gecarcinus quadratus de Saussure, 1853 ( 60 $\mathrm{mm})$. It is smaller than the maximum size of 7. planatus (82 versus $100 \mathrm{~mm}$, respectively), but an active search for the largest crabs on Malpelo was not initiated (maximum sizes taken from Türkay [1970] and Fischer et al. [1995]).

Size and weight differences between sexes in 7. malpilensis are due to the larger CW and chelae in males, typical of other species of land crabs (Hartnoll 1982, 1988). This size difference between sexes could result from the high risk for females during release of larvae so that they never reach potential maximum size. Herreid (1967) and Henning (1975) suggested that the smaller size of the adult females of $C$. guanbumi (with respect to males) is due to a lesser longevity associated with the risks implied in the migration and subsequent release of larvae of that species. Similarly, Hartnoll et al. (2006) suggested that the smaller size of females of Gecarcinus ruricola (Linnaeus, 1758) might be attributed to the risks associated with migration. Our observations during release of larvae of 7 . malpilensis, when some females were swept away by the waves, suggest that at least some females are lost. However the frequency of such losses has not been estimated. In addition it is believed that the energy costs for reproduction are higher for females than for males, and therefore females are limited to smaller sizes due to slower growth rates (Herreid 1967, Hartnoll 1988, Hartnoll et al. 2006). Nevertheless, slower growth rates may imply a delay in reaching a maximum size but not necessarily the impossibility of reaching it.
There are no previous studies on the density of 7. malpilensis. Environmental conditions differ, but in comparison with densities of 7 . planatus in Socorro Island (Pérez-Chi 2005) average values in Malpelo are greater: $1.1 \mathrm{~m}^{-2}$ (adults and juveniles) versus $\sim 0.08$ $\mathrm{m}^{-2}$, respectively. However, density is lower than $\sim 6 \mathrm{~m}^{-2}$ on Clipperton (Ehrhardt and Niaussat 1970). With respect to G. ruricola, another typical island species in the Caribbean, in Santa Catalina Island (very similar in emerged surface to Malpelo, though with a substantial vegetation cover) Hartnoll et al. (2006) found average values of 0.4 adults $\mathrm{m}^{-2}$. This is very close to the adult density of 0.41 $\mathrm{m}^{-2}$ on Malpelo. However the juvenile density on Malpelo appears to be greater than those found in Santa Catalina and Providencia for G. ruricola, where recruitment has been suggested as sporadic (Hartnoll and Clark 2006; R. Hartnoll, pers. comm.).

In contrast to other gecarcinids that show moderate fidelity to their burrows, particularly during the breeding season (e.g., Cardisoma guanbumi [Henning 1975]), 7. malpilensis appears to be highly peregrine and not dependent on a fixed refuge. Nevertheless, the distances we recorded for $\mathcal{F}$. malpilensis are not comparable with the many kilometers that some other gecarcinids may travel during their massive breeding migrations (e.g., $G e-$ carcoidea natalis [Hicks 1985]); of course, the islands where other gecarcinids live are much larger than Malpelo, which makes comparisons difficult.

Distribution in Malpelo is not homogeneous, due to the regular food source in the Cabañas sector that raises density compared with the rest of the island. Also, during release of larvae, the crab density in the supratidal zone is greater than usual, because hundreds of ovigerous females and males seeking copulation concentrate there. In other islands of the tropical eastern Pacific 7. planatus also has a patchy distribution, but the factors affecting such distribution are also related to the presence of substantial vegetation covers on those islands (e.g., Clipperton [Ehrhardt and Niaussat 1970] and Socorro Island [Jiménez et al. 1994]).

The behavior of $\mathcal{7}$. malpilensis follows what 
in other land crab species has been described as a circadian rhythm (see Burggren and McMahon 1988). The crab is much more active at dusk, night, and dawn than in daylight. However, contrary to 7 . planatus in Socorro and Gorgona islands (Pérez-Chi 2005; M.L.-V., unpubl. data), it might not be consider a nocturnal crab in a strict sense but rather a partially diurnal species with higher nocturnal activity.

Fobngarthia malpilensis reproduces during a major portion of the year, at least during the rainy season (from May to December), but without concentrated mass migrations. It differs from some other gecarcinids that have marked seasonal reproductive behavior, often with massive migrations: examples are $G$. ruricola in Providence Island, Colombia (Hartnoll and Clark 2006); Gecarcoidea natalis in Cristmas Island, Australia (Hicks 1985); and Gecarcinus lateralis in Florida, USA, and Bermuda (Bliss et al. 1978). Nevertheless, the general scheme of larval release into the sea during the days of highest tides of the lunar cycle matches that found in several other gecarcinids (e.g., G. lateralis [Klaassen 1975, Bliss et al. 1978], C. guanbumi [Henning 1975]).

Based on growth estimations from megalops of G. ruricola recruited in Providence Island (Hartnoll and Clark 2006, Hartnoll et al. 2006) and on a megalop maximum size of 3 $\mathrm{mm}$ for 7 . planatus reared in the laboratory (Cuesta et al. 2007), juveniles with a CW of less than $6 \mathrm{~mm}$ should not be older than 6 months. This renders it probable that over a good portion of the year, except perhaps in the dry season (from the end of December to April), recruitment of 7 . malpilensis occurs on Malpelo. This is reassuring, because larval dispersal in the plankton is at the mercy of wind and currents and could make return to Malpelo uncertain.

In contrast to 7 . planatus on Socorro Island, which is regularly preyed upon by land birds (Rodríguez-Estrella et al. 1996), f. malpilensis is only preyed on sporadically by small numbers of migratory birds. Its role within the Malpelo trophic network is multiple and depends on its stage of development. When juvenile it is a prey of lizards, migratory birds, and even adult crabs, whereas when adult it is an opportunist omnivore, scavenger, and recycler of organic material. Except for the lizard D. millepunctatus, which on some occasions is even preyed upon by the crab, 7 . malpilensis has no other important natural predators.

On the basis of average density and weight and distribution of crabs, the estimated total biomass of 7 . malpilensis on the island is nearly 30 tons. By removing the algal cover and eating, in practice, every type of organism, the Malpelo crab is the major transformer as a recycler of organic matter in the trophic network of the island. Its contribution in excrement must form an important component of the scarce soils of Malpelo, and its persistent grazing keeps this soil almost totally free of higher vegetation, in the same way that other land crab species control the seedling recruitment in tropical forests (e.g., Gecarcoidea natalis in Christmas Island [Green et al. 1997], Gecarcinus quadratus in Costa Rica [Sherman 2002]). These characteristics make 7. malpilensis one of the main constituents (perhaps the most important) within the trophic network of Malpelo.

\section{ACKNOWLEDGMENTS}

We are grateful to M. Rodríguez, P. Herrón, S. García, F. A. Estela, J. C. Botello, and J. Zamudio for assistance in the field. R. Pitman kindly shared his observations on land crabs of several islands in the tropical eastern $\mathrm{Pa}$ cific. The manuscript was improved based on comments and suggestions from R. Hartnoll and two anonymous reviewers. M. Mendoza and S. Graham helped to improve a preliminary English version.

\section{Literature Cited}

Bliss, D. E., J. Van Montfrans, M. Van Montfrans, and J. R. Boyer. 1978. Behaviour and growth of the land crab Gecarcinus lateralis (Freminville) in southern Florida. Bull. Am. Mus. Nat. Hist. 160:113-151.

Brando, A., H. von Prahl, and J. R. Cantera. 1992. Malpelo: Isla oceánica de Colombia. 
Banco de Occidente. Santiago de Cali, Colombia.

Burggren, W. W., and B. R. McMahon. 1988. Biology of the land crabs. Cambridge University Press, Cambridge.

Cuesta, J. A., M. U. García-Guerrero, and M. E. Hendrickx. 2007. The complete larval development of Fohngarthia planatus (Brachyura: Grapsoidea: Gecarcinidae) described from laboratory reared material, with notes on the affinity of Gecarcinus and Fobngarthia. J. Crustacean Biol. 27:263-277.

Ehrhardt, J. P., and P. Niaussat. 1970. Écologie et physiologie du brachyoure terrestre Gecarcinus planatus Stimpson (D'aprés les individus de L'Atoll de Clipperton). Bull. Soc. Zool. Fr. 95 (1): 41-54.

Faxon, W. 1893. Preliminary descriptions of new species of Crustacea. Bull. Mus. Comp. Zool. Harv. Coll. 24 (7): 149-220.

Fischer, W., F. Krupp, W. Schneider, C. Sommer, K. Carpenter, and V. Niem. 1995. Guía FAO para la identificación de especies para los fines de la pesca Pacífico Centro-Oriental. 2-3: 647-1813. FAO, Rome.

Garth, J. S. 1948. The Brachyura of the Askoy Expedition: With remarks on carcinological collecting in the Panama Bight. Bull. Am. Mus. Nat. Hist. 92:1-66.

Graham, J. B. 1975. The biological investigation of Malpelo Island, Colombia. Smithson. Contrib. Zool. 176:1-8.

Green, P. T., D. J. O'Dowd, and P. S. Lake. 1997. Control of seedling recruitment by land crabs in rain forest on a remote oceanic island. Ecology 78:2474-2486.

Hartnoll, R. G. 1982. Growth. Pages 119116 in D. E. Bliss and L. G. Abele, eds. The biology of Crustacea. Vol. 2, Embryology, morphology and genetics. Academic Press, New York.

. 1988. Growth and molting. Pages 186-210 in W. W. Burggren and B. R. McMahon, eds. Biology of the land crabs. Cambridge University Press, Cambridge.

Hartnoll, R. G., M. S. P. Baine, Y. Grandas, J. James, and H. Atkin. 2006. Population biology of the black land crab, Gecarcinus ruricola, in the San Andrés Archipelago, western Caribbean. J. Crustacean Biol. 26:316-325.

Hartnoll, R. G., and P. F. Clark. 2006. A mass recruitment event in the land crab Gecarcinus ruricola (Linnaeus, 1758) (Brachyura: Grapsoidea: Gecarcinidae), and a description of the megalop. Zool. J. Linn. Soc. 146:149-164.

Henning, H. G. 1975. Kampf-, Fortpflanzungs- und HautungsverhaltenWachstum und Geschlechtsreife von Cardisoma guanbumi Latreille (Crustacea, Brachyura). Forma Functio 8:463-510.

Herreid, C. F. 1967. Skeletal measurements and growth of the land crab Cardisoma guanbumi Latreille. Crustaceana (Leiden) 13:39-44.

Hicks, J. W. 1985. The breeding behaviour and migrations of the terrestrial crab $G e-$ carcoidea natalis (Decapoda: Brachyura). Aust. J. Zool. 33:127-142.

Jiménez, C., A. Ortega-Rubio, S. AlvarezCárdenas, and G. Arnaud. 1994. Ecological aspects of the land crab Gecarcinus planatus (Decapoda: Gecarcinidae) in Socorro Island, Mexico. Biol. Conserv. 69:9-13.

Klaassen, F. 1975. Ökologische und ethologische Untersuchungen zur Fortpflanzungsbiologie von Gecarcinus lateralis (Decapoda, Brachyura). Forma Functio 8:101-174.

López-Victoria, M., and D. Rozo. 2006. Model-based geomorphology of Malpelo Island and spatial distribution of breeding seabirds. Bol. Invest. Mar. Cost. 35:111131.

Ng, P. K. L., and D. Guinot. 2001. On the land crabs of the genus Discoplax A. Milne-Edwards, 1867 (Crustacea: Decapoda: Brachyura: Gecarcinidae), with description of a new cavernicolous species from the Philippines. Raffles Bull. Zool. 49:311-338.

Pérez-Chi, A. 2005. Densities, diel activity, burrow shape, and habitat characteristics of Gecarcinus (7ohngarthia) planatus Stimpson, 1860 (Decapoda, Brachyura, Gecarcinidae) at Socorro Island, Revillagigedo, Mexico. Crustaceana (Leiden) 78:255272.

Pitman, R. L., and J. R. Jehl. 1998. Geo- 
graphic variation and reassessment of species limits in the "Masked" Boobies of the eastern Pacific Ocean. Wilson Bull. 110:155-170.

Prahl, H. von. 1990. Malpelo la roca viviente. Financiera Eléctrica Nacional Colombia, Editorial Presencia, Bogotá.

Rathbun, M. J. 1918. The grapsoid crabs of America. Bull. U.S. Natl. Mus. 97:1-461.

Rodríguez-Estrella, R., J. L. León de la Luz, A. Breceda, A. Castellanos, J. Cancino, and J. Llinas. 1996. Status, density and habitat relationships of the endemic terrestrial birds of Socorro Island, Revillagigedo Islands, Mexico. Biol. Conserv. 76:195-202.

Sherman, P. M. 2002. Effects of land crabs on seedling densities and distributions in a mainland neotropical rain forest. J. Trop. Ecol. 18:67-89.

Türkay, M. 1970. Die Gecarcinidae Amerikas. Mit einem Anhang über Ucides Rathbun (Crustacea: Decapoda). Senckenb. Biol. 51:333-354.

- 1987. Landkrabben. Nat. Mus. 117:143-150.

Wolcott, T. G. 1988. Ecology. Pages 55-96 in W. W. Burggren and B. R. McMahon, eds. Biology of the land crabs. Cambridge University Press, Cambridge.

Wolda, H. 1975. The ecosystem on Malpelo Island. Smithson. Contrib. Zool. 176:2126. 
